\title{
Effect of soil amendment with Chenopodium album dry biomass and two Trichoderma species on growth of chickpea var. Noor 2009 in Sclerotium rolfsii contaminated soil
}

\author{
Amna Ali, Arshad Javaid* (D), Amna Shoaib and lqra Haider Khan
}

\begin{abstract}
Sclerotium rolfsii is a soil-borne plant pathogen that causes root diseases in hundreds of plant species. It also causes collar rot disease in chickpea (Cicer arietinum L.). The present pot study was carried out to investigate the effect of soil amendment with dry biomass of a weed Chenopodium album L. and two antagonistic fungi, namely Trichoderma harzianum and T. viride, on growth and yield of chickpea variety Noor 2009 in soil infected with S. rolfsii. The pathogen-contaminated soil was amended either with 1, 2, or 3\% C. album dry biomass, T. harzianum, and T. viride alone, or combinations of either of the two Trichoderma species and plant dry biomass. The lowest shoot and root dry biomass and grain yield of chickpea were recorded in S. rolfsii inoculation alone without any soil amendment (positive control). Plant growth and yield were significantly and gradually increased over positive control with an increase in C. album dry biomass application in the soil. Likewise, soil application of either of the two Trichoderma species significantly enhanced plant growth and yield over positive control under biotic stress of S. rolfsii. Combined application of either T. harzianum or T. viride with $3 \%$ dry biomass of C. album also proved highly effective in alleviating biotic stress of S. rolfsii on growth and yield of chickpea.
\end{abstract}

Keywords: Biological control, Chenopodium album, Chickpea var. Noor 2009, Collar rot, Trichoderma spp

\section{Background}

Sclerotium rolfsii is a soil-borne phytopathogen commonly found in tropical and sub-tropical regions of the world (Sumi et al. 2018). It causes collar rot, root rot, foot rot, and wilt diseases in more than 500 plant species (Sun et al. 2020). Of these, collar rot caused by S. rolfsii is the major limiting constrain in chickpea cultivation, which causes considerable yield losses up to $45 \%$ (Sarkar et al. 2014). The pathogen has the capability of producing excessive sclerotia that may persist in the soil for several years in the form of resistant resting structures under humid weather condition (Harlton et al. 1995). The typical

*Correspondence: arshad.iags@pu.edu.pk; arshadjpk@yahoo.com Institute of Agricultural Sciences, University of the Punjab, Lahore, Pakistan symptoms of the disease include rapid plant wilting with dark brown lesions at the stem base which later on girdles the main stem. Infected plant tissues also show a white mycelial growth that often radiates over the soil surface (Acabal et al. 2019). Because of resistant sclerotia formation, the control of collar rot pathogen is not easy, and it implies a combination of biological, cultural, and chemical approaches (Dwivedi and Prasad 2016).

The use of chemical fungicides is an effective management strategy, but keeping in view the complexities arising from their usage has led the scientists to adopt some alternative practices (Shrestha et al. 2020). In recent years, the application of natural plant products and biocontrol agents have provided a promising alternate to 
the existing fungicides for more effective disease control with less hazardous impact on environment, wild life, human health, and beneficial microbes (Javaid et al. 2020). Products obtained from plants are a rich source of bioactive substances that are eco-friendly, curative, and protective against many fungal diseases (Khan and Javaid 2020). Chenopodium album belongs to family Chenopodiaceae is widely distributed in Asia, Europe, and North America (Krak et al. 2016). It contains flavonoids, isoflavonoids, aldehydes, saponins, polyphenols, apocarotenoid, and alkaloids (Mahour et al. 2008) with diverse antifungal activities against Fusarium oxysporum, F. solani, Pythium aphanidermatum, Ascochyta rabiei, Rhizoctonia solani, Alternaria radicina, and A. dauci (Semina et al. 2016 and Alkooranee et al. 2020).

Trichoderma genus has long been recognized as a biocontrol agent to control fungal pathogens (Rabinal and Bhat 2020). The application of Trichoderma spp. against S. rolfsii has been received a great attention because of their excellent root colonization abilities, production of antifungal metabolites, and lysis of sclerotia (Hirpara et al. 2019). The mechanism through which they suppress the growth of fungal pathogens includes induction of plant defense responses, production of cell wall degrading enzymes, antibiosis, mycoparasitism, and competition for nutrients and niches (Wonglom et al. 2019). Despite the proven antagonistic potential of Trichoderma, there is still a need to further evaluate its efficacy by using available chickpea verities grown in different geographical regions. Therefore, the present study was carried out to investigate the antifungal potential of $C$. album in combination with two Trichoderma species, namely $T$. harzianum or $T$. viride to control collar rot disease of chickpea.

\section{Materials and methods Pot trial}

For possible management of collar rot disease and subsequent improvement in growth and yield of chickpea, pot soil was amended with dry biomass of C. album and two antagonistic fungi, namely $T$. harzianum and $T$. viride, the protocol given by Javaid et al. (2017) was generally followed with some modifications.

Inoculum of $S$. rolfsii was prepared on pearl millet seeds. The seeds were moderately boiled and water was strained then seeds were air dried to remove moisture from the surface. Seeds were packed in polythene bags and autoclaved for $30 \mathrm{~min}$ at $121{ }^{\circ} \mathrm{C}$. Afterward, seeds were cooled and inoculated with discs of $S$. rolfsii and incubated for 7 days at $28{ }^{\circ} \mathrm{C}$.

In the pot trial, there were following 13 treatments:

$\mathbf{T}_{\mathbf{1}}=$ Negative control

$\mathbf{T}_{2}=$ Positive control [Sclerotium rolfsii (SR)]

$\mathbf{T}_{3}=1 \%$ C. album biomass $+\mathrm{SR}$
$\mathbf{T}_{\mathbf{4}}=2 \%$ C. album biomass $+\mathrm{SR}$

$\mathbf{T}_{5}=3 \%$ C. album biomass $+\mathrm{SR}$

$\mathbf{T}_{\mathbf{6}}=T$. harzianum $(\mathrm{TH})+\mathrm{SR}$

$\mathbf{T}_{7}=$ T. viride $(\mathrm{TV})+\mathrm{SR}$

$\mathbf{T}_{\mathbf{8}}=1 \%$ C. album biomass $+\mathrm{TH}+\mathrm{SR}$

$\mathbf{T}_{\mathbf{9}}=2 \%$ C. album biomass $+\mathrm{TH}+\mathrm{SR}$

$\mathbf{T}_{\mathbf{1 0}}=3 \%$ C. album biomass $+\mathrm{TH}+\mathrm{SR}$

$\mathbf{T}_{\mathbf{1 1}}=1 \%$ C. album biomass $+\mathrm{TV}+\mathrm{SR}$

$\mathbf{T}_{12}=2 \%$ C. album biomass $+\mathrm{TV}+\mathrm{SR}$

$\mathbf{T}_{13}=3 \%$ C. album biomass $+\mathrm{TV}+\mathrm{SR}$

Each treatment had five replicates and pots were arranged in a completely randomized design.

The soil used in the experiment was sandy loam in texture having $\mathrm{pH} 7.7,95 \mathrm{mg} \mathrm{kg}^{-1}$ potassium, $6.3 \mathrm{mg}$ $\mathrm{kg}^{-1}$ phosphorous, and $0.84 \%$ organic matter. Soil was fumigated with formylene-dipped cotton swabs and was covered with polythene sheet for 1 week to eliminate any kind of pathogens and insects. Thereafter, polythene sheet and cotton swabs were removed and soil was left for 1 week to evaporate any traces of the fumigant.

Earthen pots of $27 \mathrm{~cm}$ diameter were filled with $5 \mathrm{~kg}$ fumigated soil in each pot. Inoculum of S. rolfsii, prepared on pearl millet seeds, was thoroughly mixed in soil of each pot at $50 \mathrm{~g}$ per pot. After that, pots were irrigated and left for a week under natural environmental conditions for development of the pathogen in the soil. The pathogen was mixed in the soil of all the pots except those of negative control. In negative control, however, same amount of autoclaved pearl millet seeds was mixed in the pot soil. After 1 week, inocula of T. harzianum and T. viride were mixed in soil of the respective pots at $50 \mathrm{~g}$ per pot. In remaining pots, same amount of boiled pearl millet seeds was mixed. Pots were again left for 1 week after irrigation with a good quality tap water. After that, dry biomass of C. album was mixed at 1, 2, and $3 \%(\mathrm{w} / \mathrm{w})$ in soil of respective pots, irrigated with tap water and left for 1 week for stabilizing the conditions.

Seeds of chickpea variety Noor 2009 were surface sterilized by $1 \%$ sodium hypochlorite solution for $3 \mathrm{~min}$. After thorough washing with sterilized water, 20 seeds of each variety per pot were sown. Once seeds were germinated, thinning was done to sustain 10 uniform seedlings per pot. Pots were watered according to the requirement of the crop.

Plants were harvested at maturity. Data for total pod and seed weight, and root and shoot length were recorded. Plant materials were placed in an oven at $60{ }^{\circ} \mathrm{C}$ to constant weight and finally root and shoot biomasses were recorded in gram.

\section{Physiological bioassays}

Total chlorophyll and carotenoids extraction were carried out by mixing of $500 \mathrm{mg}$ fresh leaf material (at 
flowering sage) in $80 \%$ of chilled ethanol $(10 \mathrm{ml})$. Mixture was homogenate at $800 \mathrm{rpm}$ for $15 \mathrm{~min}$ using centrifuge machine. The supernatant was evaluated for chlorophyll content. The absorbance was checked for chlorophyll a at $645 \mathrm{~nm}$, for chlorophyll b at $663 \mathrm{~nm}$, and for carotenoids at $470 \mathrm{~nm}$ by UV-spectrophotometer. The observed values were analyzed quantitatively, and the amount of chlorophyll was estimated by using the formula of Lichtenthaler and Buschmann (2001). The quantities of chlorophyll and carotenoid content were expressed as $\mathrm{mg}$ $\mathrm{g}^{-1}$ of fresh plant weight.

Leaves and root samples of each treatment were collected at flowering stage for enzyme assays. One gram of sample from each treatment was grinded in pre chilled liquid nitrogen with $0.1 \mathrm{M}$ sodium phosphate buffer $(4 \mathrm{ml})$ using pestle and mortar. Centrifugation of the mixture was done for $15 \mathrm{~min}$ at 1000 rpm. The supernatant was considered as crude enzyme extract for evaluating phenyl alanine ammonia lyase (PAL) and catalase (CAT) activities (Ramanujam et al. 2012). Estimation of phenyl PAL and CAT activities were carried following procedures of Dikerson et al. (1984) and Beers and Sizer (1952), respectively. The enzyme activity was expressed as $\mathrm{U} \mathrm{min}^{-1} \mathrm{mg}^{-1}$ of protein. For estimation of phenolic content, methodology of Malik and Singh (1980) was adopted and

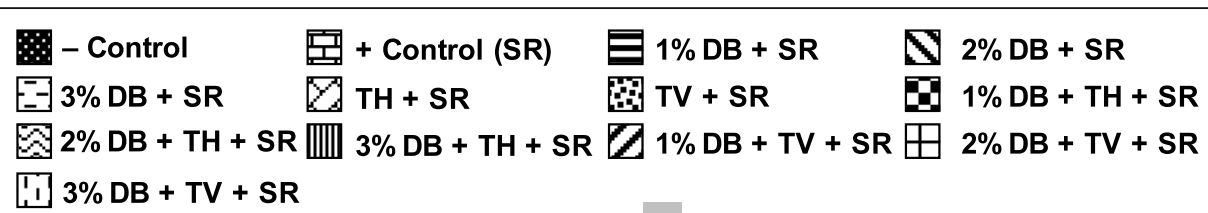

A $\quad H^{-05}=1.93$
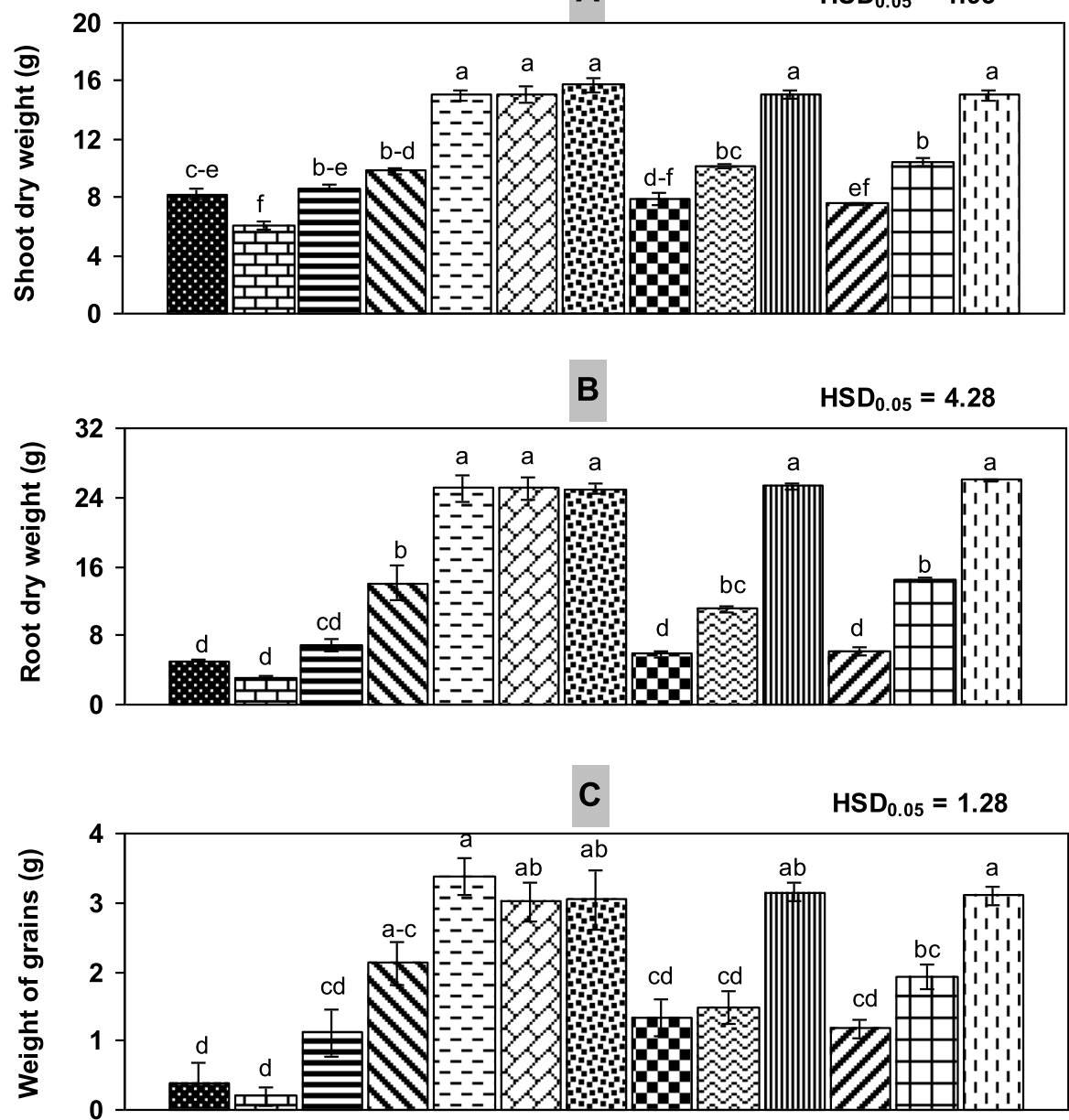

Treatments

Fig. 1 Effect of Sclerotium rolfsii (SR), Trichoderma harzianum (TH), T. viride (TV), and dry biomass (DB) of Chenopodium album on growth and yield of chickpea var. Noor 2009. Vertical bars show standard errors of means of five replicates. Values with different letters at their top show significant difference $(p \leq 0.05)$ as determined by Tukey's HSD test 
the quantity of total phenol was expressed in $\mathrm{mg} \mathrm{g}^{-1}$ of fresh plant weight.

\section{Statistical analysis}

All data were subjected to analysis of variance (ANOVA), followed by Tukey's HSD test to delineate the treatment means at $p \leq 0.05$ using computer software Statistix 8.1.

\section{Results and discussion}

Effect of soil amendments on plant growth and yield

Shoot dry weight in negative control was $8.2 \mathrm{~g}$ that was decreased to $6.02 \mathrm{~g}$ on inoculation of $S$. rolfsii resulting in $26 \%$ decrease in positive control as compared to negative control. Application of dry biomass of C. album (DBC) significantly $(p \leq 0.05)$ increased shoot dry weight that gradually increased by increasing dose of DBC. As a result, there was $42-148 \%$ increase in chickpea shoot dry weight due to different doses of DBC over positive control. Separate applications of T. harzianum and $T$. viride also enhanced shoot dry weight tremendously by 148 and $159 \%$ over positive control, respectively. The effect of combined application of C. album + T. harzianum and C. album + T. viride was similar to that of their separate applications, and there was no any synergistic effect of the combined application of DBC and the biological control agents (Fig. 1a). S. rolfsii inoculation reduced root dry biomass by $34 \%$ than the negative control. Application of 3\% dry biomass of C. album alone or combined with application of either T. harzianum or $T$. viride exhibited tremendous increase in dry biomass of root that was $681-712 \%$ higher than positive control. The effect of separate application of either $T$. harzianum or $T$. viride was similar to effect of $3 \%$ C. album amendment (Fig. 1b). The lowest grain yield viz. $0.20 \mathrm{~g}$ was recorded in positive control. Different soil amendment treatments increased the yield variably and significantly. It was gradually and significantly increased with an increase in DBC as soil amendment. Grain yield was increased to 1.12, 2.12, and $3.37 \mathrm{~g}$ due to 1,2 , and $3 \%$ soil amendments with DBC that was 460,960 , and $1585 \%$ higher than the positive control, respectively. Applications of $T$. harzianum and T. viride either alone or combined with $3 \%$ C. album biomass had an effect on yield
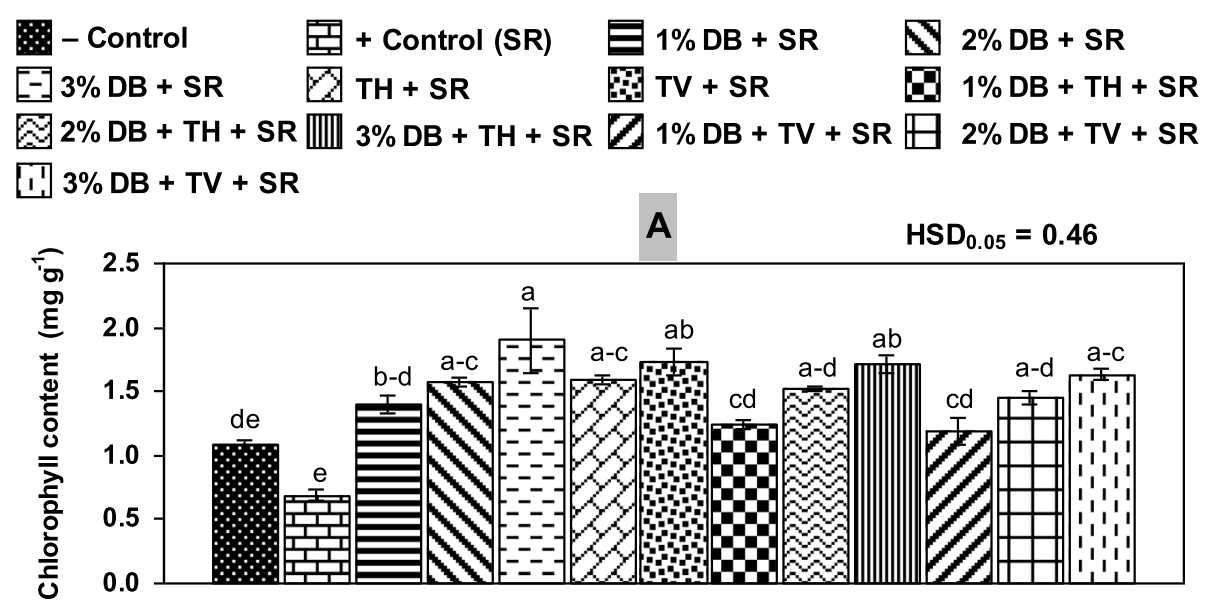

Treatments

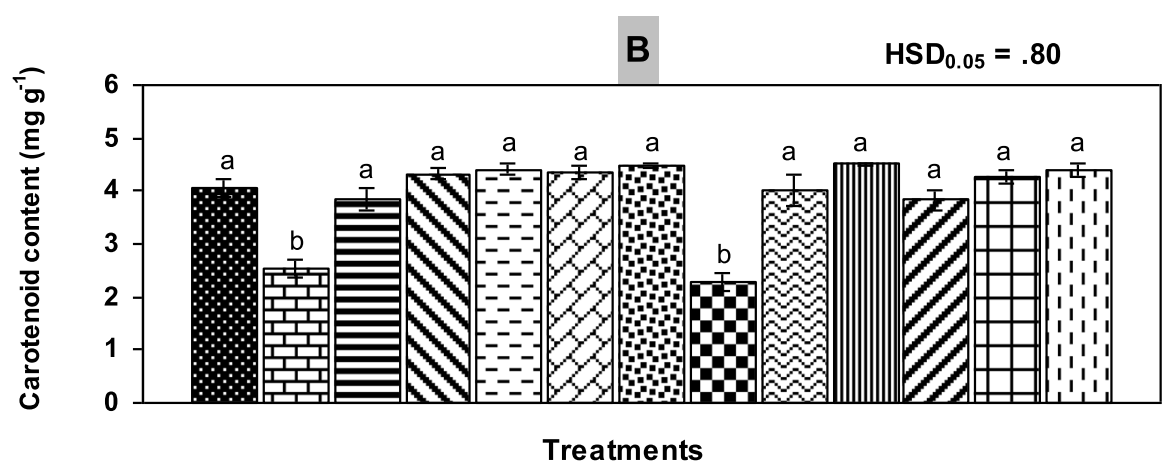

Fig. 2 Effect of Sclerotium rolfsii (SR), Trichoderma harzianum (TH), T. viride (TV), and dry biomass (DB) of Chenopodium album on leaf chlorophyll and carotenoid content of chickpea var. Noor 2009. Vertical bars show standard errors of means of five replicates. Values with different letters at their top show significant difference $(p \leq 0.05)$ as determined by Tukey's HSD test 
that was very much similar to the effect of $3 \% \mathrm{DBC}$ alone amendment (Fig. 1c).

The use of organic amendments can enhance suppressive ability of the soil against soil-borne pathogens (van Elsas and Postma 2007). The effect, however, differed with respect to environmental conditions and the type of pathogen (Janvier et al. 2007). There were many successful stories where soil organic amendments such as dry biomass of Datura metel, Coronopus didymus, and Withania somnifera controlled charcoal rot of mung bean caused by Macrophomina phaseolina, collar rot of chilies caused by S. rolfsii, and basal rot of onion caused by $\mathrm{Fu}$ sarium oxysorum f. sp. cepae, respectively (Javaid and Saddique 2011; Javaid and Iqbal 2014 and Akhtar and Javaid 2017). The phenomenon of disease suppression has been commonly related to change in physicochemical properties, microbial populations and related processes in the soil (Bonanomi et al. 2010). In the present study, application of 3\% dry biomass of C. album alone or combined with $T$. harzianum and $T$. viridi markedly enhanced root and shoot growth, pod weight, and grain yield of chickpea variety Noor 2009 under biotic stress of $S$. rolfsii. The decomposition of the dried biomass material of C. album possibly released some chemical constituents in the rhizospheric soil especially saponins, which in turn suppressed the growth and spread of the target pathogenic fungus. Javaid and Rauf (2015) reported that application of 3\% leaf dry biomass of $C$. album significantly reduced incidence of basal rot of onion by $63 \%$ and plant mortality by $89 \%$ and improved crop growth of onion significantly. Similar work was done by Riaz et al. (2010) against Fusarium oxysporum $\mathrm{f}$. sp. gladioli in which leaf residues of different plants significantly decreased disease incidence as well as disease severity. Results of the present study showed that when either T. harzianum or T. viridi were used in combination with 3\% dry biomass of C. album, the effect on plant growth and yield was same as that of application of $3 \%$ dry biomass alone. By contrast, recently Javaid et al. (2017) reported that application of dry biomass of a brassicaceous weed Sisymbrium irio in combination with $T$. harzianum gave significantly higher crop growth and yield of mung bean when compared to application of either alone.

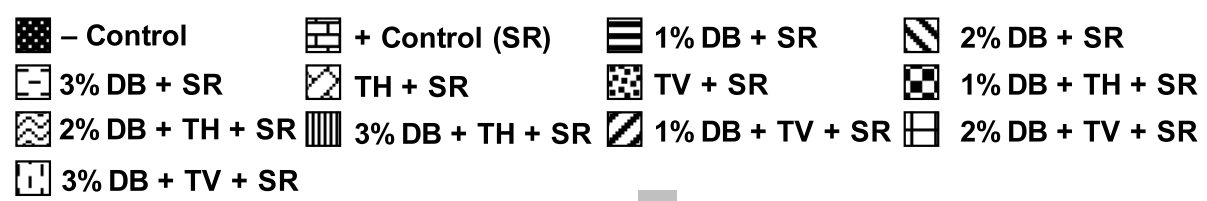

1. $3 \% \mathrm{DB}+\mathrm{TV}+\mathrm{SR}$

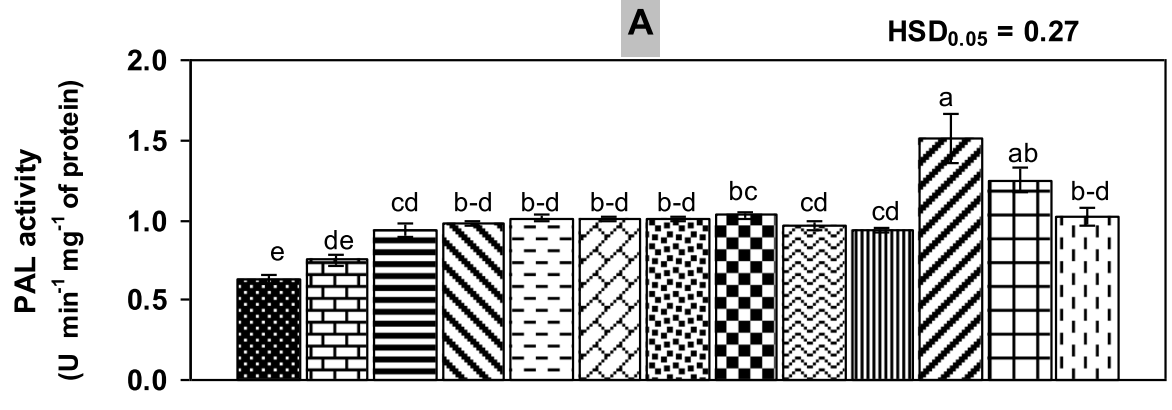

Treatments

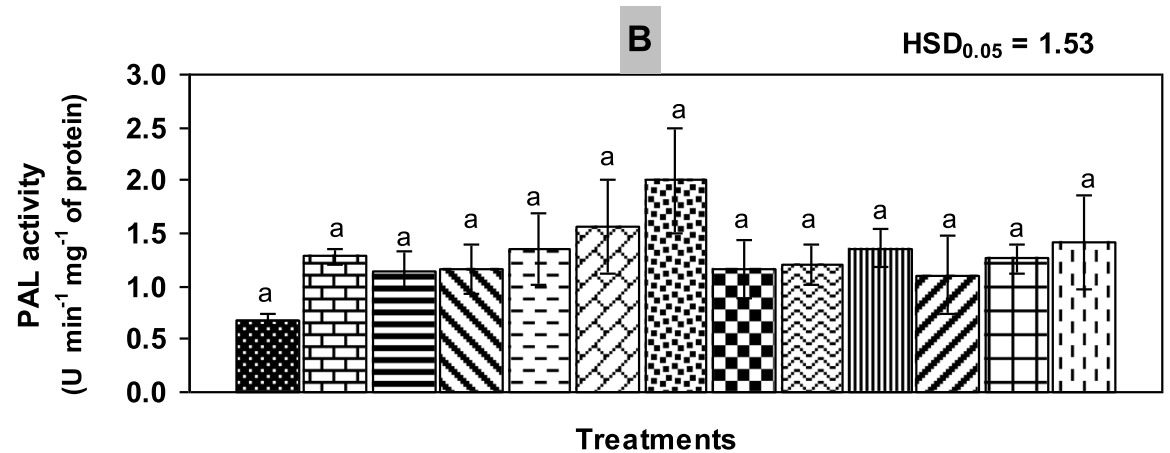

Fig. 3 Effect of Sclerotium rolfsii (SR), Trichoderma harzianum (TH), T. viride (TV), and dry biomass (DB) of Chenopodium album on leaf and root polyphenol ammonia lyase (PAL) activity of chickpea var. Noor 2009. Vertical bars show standard errors of means of five replicates. Values with different letters at their top show significant difference $(p \leq 0.05)$ as determined by Tukey's HSD test 
In the present study, individual application of either $T$. harzianum or $T$. viridi significantly enhanced crop growth and yield under stress of $S$. rolfsii. Earlier studies showed that Trichoderma spp. were very beneficial fungi and had the ability to control many pathogens by various biological means (Vinodkumar et al. 2017). The modes of action of Trichoderma were competition, antagonism and production of some compounds in the soil against fungal pathogens (Jorge 2014). Recently, Liu et al. (2020) reported that Trichoderma afroharzianum reduced incidence of Syringa powdery mildew of Syringa oblata. They also induced production of abscisic acid that resulted in shedding of infected leaves and formation of new ones. Other recent studies also showed that different isolates of Trichoderma spp. had the ability to reduce the severity of foliar and root diseases (Muthukathan et al. 2020), presumably by inducing systemic resistance in plants (Maurya et al. 2008).

\section{Effect of soil amendments on plant physiology}

The lowest chlorophyll content $\left(0.69 \mathrm{mg} \mathrm{g}^{-1} \mathrm{FW}\right)$ was recorded in positive control. The application of dry biomass of C. album, T. harzianum, and T. viride significantly increased the chlorophyll content than in the positive control. The highest chlorophyll content (1.9 $\mathrm{mg} \mathrm{g}^{-1}$ ) was recorded in $3 \%$ dry biomass of C. album, followed by treatments inoculated with $T$. harzianum and $T$. viride separately or combined with $3 \%$ dry biomass of C. album (Fig. 2a).

The lowest carotenoid content $\left(2.30 \mathrm{mg} \mathrm{g}^{-1}\right)$ was revealed in T. harzianum plus $1 \%$ dry biomass of C. album and positive control $\left(2.53 \mathrm{mg} \mathrm{g}^{-1}\right)$ treatments. In general, in the rest of the treatments, application of dry biomass of C. album, T. harzianum, and T. viride significantly increased the carotenoids content as compared to positive control. Carotenoid content in these treatments was in the range of 3.83 to $4.48 \mathrm{mg} \mathrm{g}^{-1}$ (Fig. $2 \mathrm{~b}$ ).

The lowest PAL activity in both leaf and root, i.e., 0.63 and $0.68 \mathrm{U} \mathrm{min} \mathrm{mg}^{-1} \mathrm{mg}^{-1}$ of protein, respectively, was recorded in negative control. All the $S$. rolfsii-inoculated treatments increased PAL activity to variable extents. PAL activity in leaves and roots of positive control was $19 \%$ and $88 \%$ higher over negative control, respectively. In leaves, PAL activity was further increased by
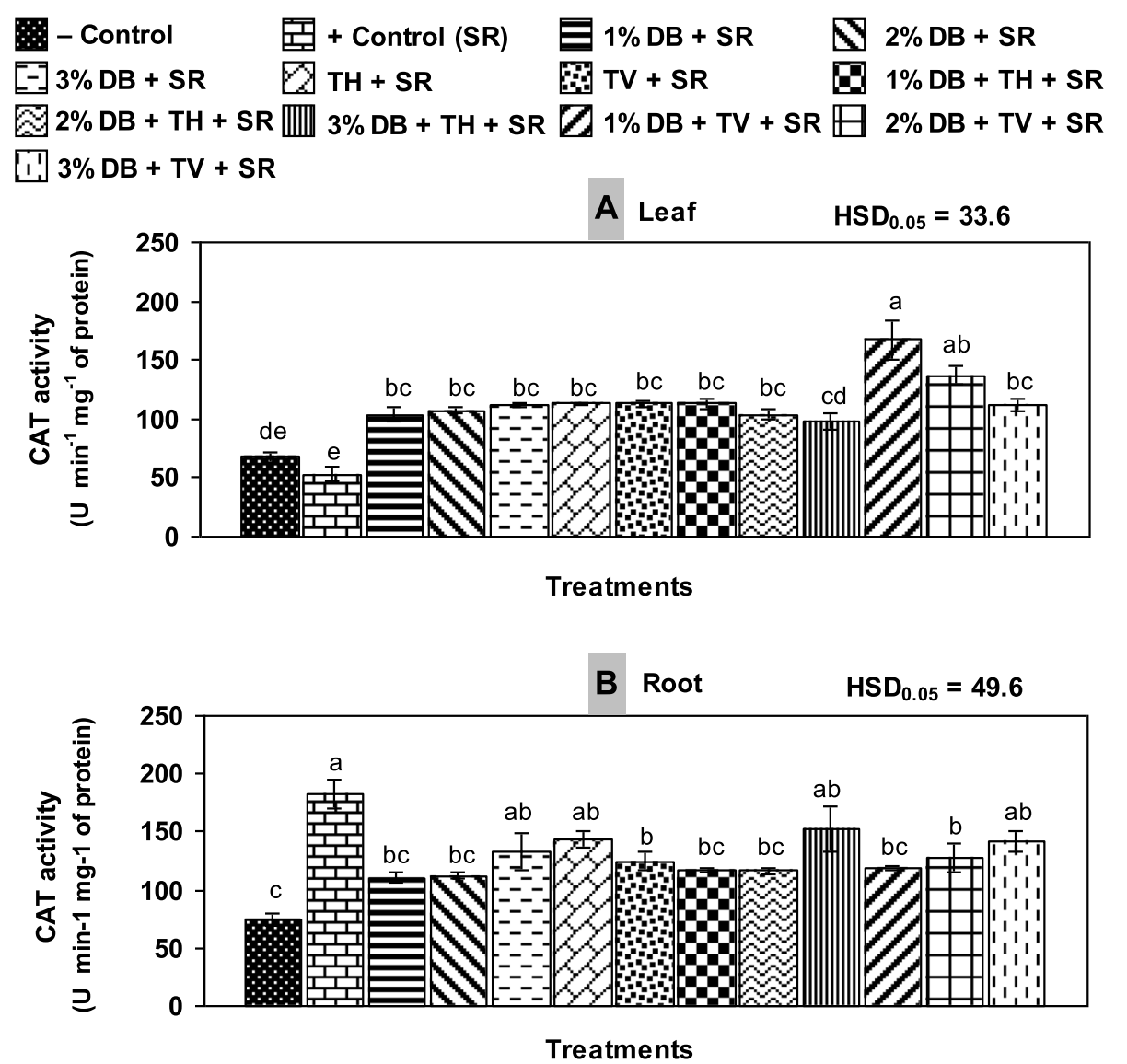

Fig. 4 Effect of Sclerotium rolfsii (SR), Trichoderma harzianum (TH), T. viride (TV), and dry biomass (DB) of Chenopodium album on leaf and root catalase activity (CAT) of chickpea var. Noor 2009. Vertical bars show standard errors of means of five replicates. Values with different letters at their top show significant difference $(p \leq 0.05)$ as determined by Tukey's HSD test 
application of soil amendments in S. rolfsii inoculated plants that was 49-98 and 25-67\% higher than negative and positive control treatments, respectively (Fig. 3a). However, in roots, PAL activity was marked higher than either negative or positive control treatments only in $T$. viride inoculated plant (Fig. 3b).

In leaves, the effect of $S$. rolfsii inoculation on CAT activity was insignificant. By contrast, in root $S$. rolfsii inoculation increased CAT activity to its highest value of $182 \mathrm{U}$ $\mathrm{min}^{-1} \mathrm{mg}^{-1}$ of protein as compared to $74 \mathrm{U} \mathrm{min}^{-1} \mathrm{mg}^{-1}$ of protein in negative control. In general, CAT activity in leaves was significantly higher in C. album- and Trichoderma-amended treatments as compared to negative and positive control treatments. However, the highest CAT value (167 $\mathrm{U} \mathrm{min}{ }^{-1} \mathrm{mg}^{-1}$ of protein) was recorded in $1 \%$ C. album $+T$. viride treatment (Fig. 4a). In roots, CAT activity in different C. album and Trichoderma treatments were $50-105 \%$ higher than negative control and 16-39\% lower than positive control (Fig. 4b).

Data presented in Fig. 5 indicate that $S$. rolfsii inoculation increased phenolic content in leaves and roots. The effect was more pronounced and significant in leaves than in roots where $40 \%$ increase in phenolic content was evident in leaves over negative control. Application of different concentrations of C. album dry biomass as soil amendment significantly enhanced phenolic content in leaves as well as in roots over control. Similar effect was observed on phenolic content of leaf due to application of T. harzianum and T. viride, either alone or in combination with $3 \%$ dry biomass of $C$. album. In roots, the highest phenolic content was recorded in $T$. harzianum $+3 \%$ biomass of C. album that was $58 \%$ and $45 \%$ higher than phenolic content in negative and positive control treatments, respectively.

Application of dry biomass of C. album, T. harzianum, and $T$. viride not only enhanced the growth of tomato plants but also protected them from disease by stimulating resistance through inducing greater photosynthetic pigment, phenolics, and activities of enzymes probably to appropriate level to get rid of pathogen pressure (Awan et al. 2018). Similar results have been obtained previously due to effect of soil amendment or biocontrol agents in Vigna mungo and $V$. radiata against charcoal rot caused by Macrophomina phaseolina (Javaid et al.
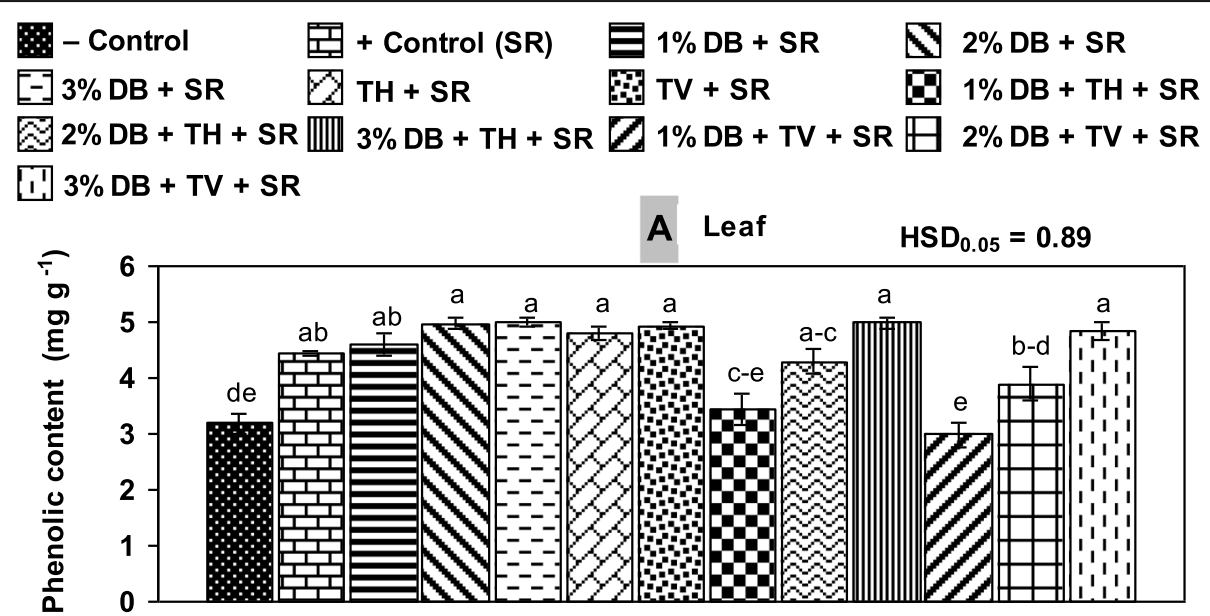

Treatments

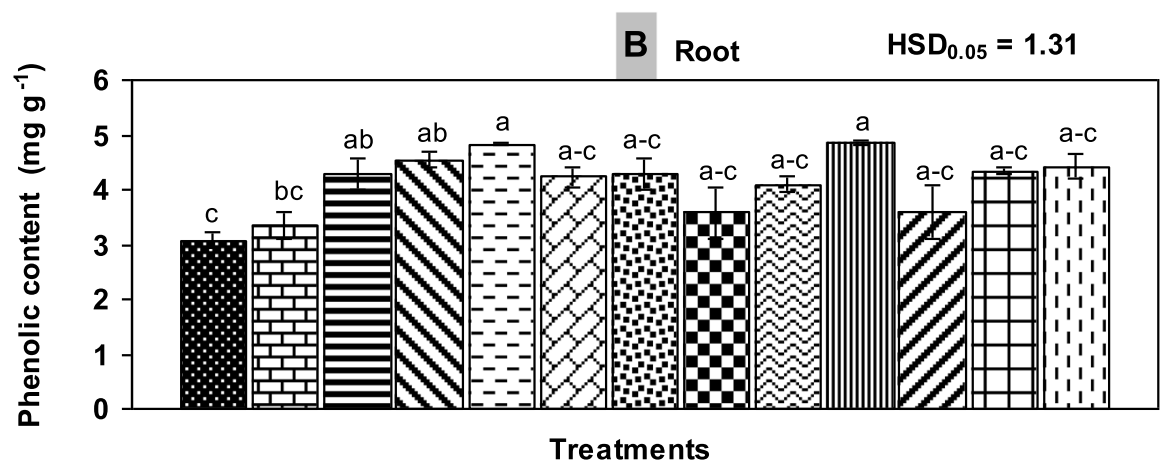

Fig. 5 Effect of Sclerotium rolfsii (SR), Trichoderma harzianum (TH), T. viride (TV), and dry biomass (DB) of Chenopodium album on leaf and root phenolic content of chickpea var. Noor 2009. Vertical bars show standard errors of means of five replicates. Values with different letters at their top show significant difference $(p \leq 0.05)$ as determined by Tukey's HSD test 
2018; Shoaib et al. 2018) and in chickpea against collar rot incited by S. rolfsii (Shoaib et al. 2019). Fungicidal action of dry biomass of C. album or Trichoderma spp. either alone as well as their synergism may act as immune booster to strengthen physiological attributes in favor of better plant health by conserving root system function (Shoaib et al. 2019).

\section{Conclusion}

This study concluded that application of 3\% dry biomass of $C$. album either alone or combined with either of the two Trichoderma species viz. T. harzianum and T. viridi, as soil amendment, resulted in the highest crop growth and yield of chickpea under the stress of $S$. rolfsii.

\section{Abbreviations}

MEA: Malt extract agar; ANOVA: Analysis of variance; DB: Dry biomass; CAT: Catalase; POX: Peroxidase; PPO: Polyphenol peroxidase; SR: Sclerotium rolfsii; TH: Trichoderma harzianum; TV: T. viride

\section{Acknowledgements}

Not applicable

\section{Authors' contributions}

AA conducted the study. AJ supervised the work, analyzed the data, and approved the final manuscript. AS supervised the part of study related to plant physiology. IHK contributed in writing the manuscript. All authors read and approved the final manuscript.

\section{Funding}

Not applicable

\section{Availability of data and materials}

The datasets used and/or analyzed during the current study are available from the corresponding author on reasonable request.

\section{Ethics approval and consent to participate}

Not applicable

\section{Consent for publication}

All authors are agreed to publish this paper.

\section{Competing interests}

The authors declare that they have no competing interests.

Received: 19 June 2020 Accepted: 29 July 2020

Published online: 06 August 2020

\section{References}

Acabal BD, Dalisay TU, Groenewald JZ, Crous PW, Cumagun CJR (2019) Athelia rolfsii (= Sclerotium rolfsii) infects banana in the Philippines. Austral Plant Dis Notes 14:10

Akhtar R, Javaid A (2017) Biological management of basal rot of onion by Trichoderma harzianum and Withania somnifera. Planta Daninha 35: e017170507

Alkooranee JT, Al-khshemawee HH, Al-badri MAK, Al-srai MS, Daweri HH (2020) Antifungal activity and GC-MS detection of leaves and roots parts of Chenopodium album extract against some phytopathogenic fungi. Indian J Agric Res 54:117-121

Beers RF, Sizer JW (1952) Spectrophotometric method for measuring breakdown of hydrogen peroxide catalase. J Biol Chem 195:133-140

Bonanomi G, Antignani V, Capodilupo M, Scala F (2010) Identifying the characteristics of organic soil amendments that suppress soil borne plant diseases. Soil Biol Biochem 42:136-144

Dikerson DP, Pascholati SF, Hagerman AE, Butler LG, Nicholson RL (1984) Phenylalanine ammonia-lyase and hydroxy cinnamate CoA ligase in maize mesocotyls inoculated with Helminthosporium maydis or Helminthosporium carbonum. Physiol Mol Plant Pathol 25:111-123

Dwivedi SK, Prasad G (2016) Integrated management of Sclerotium rolfsii: an overview. Eur J Biomed Pharm Sci 3:137-146

Harlton CE, Levesque CA, Punja ZK (1995) Genetic diversity in Sclerotium (Athelia) rolfsii and related species. Phytopathology 85:1269-1281

Hirpara DG, Gajera HP, Patel AK, Katakpara ZA, Golakiya BA (2019) Molecular insights into development of Trichoderma interfusants for multistress tolerance enhancing antagonism against Sclerotium rolfsii Sacc. J Cell Physiol 234:7368-7383

Janvier C, Villeneuve F, Alabouvette C, Edel-Hermann V, Mateille T, Steinberg C (2007) Soil health through soil disease suppression: which strategy from descriptors to indicators. Soil Biol Biochem 39:1-23

Javaid A, Afzal L, Shoaib A (2017) Biological control of charcoal rot of mungbean by Trichoderma harzianum and shoot dry biomass of Sisymbrium irio. Planta Daninha 35:e017165756

Javaid A, Afzal R, Shoaib A (2020) Biological management of southern blight of chili by Penicillium oxalicum and Leaves of Eucalyptus citriodora. Int J Agric Biol 23:93-102

Javaid A, lqbal D (2014) Management of collar rot of bell pepper (Capsicum annuum L.) by extracts and dry biomass of Coronopus didymus shoot. Biol Agric Hort 30:164-172

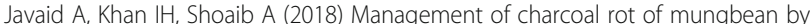
two Trichoderma species and dry biomass of Coronopus didymus. Planta Daninha 36:e018182795

Javaid A, Rauf S (2015) Management of basal rot disease of onion with dry leaf biomass of Chenopodium album as soil amendment. Int J Agric Biol 17:142148

Javaid A, Saddique A (2011) Management of Macrophomina root rot of mungbean using dry leaves manure of Datura metel as soil amendment. Span J Agric Res 9:901-905

Jorge L (2014) Trichoderma strains as bio-control agents. Adv Gen Eng 3:1

Khan $\mathrm{H}$, A Javaid (2020). Comparative antifungal potential of stem extracts of four quinoa varieties against Macrophomina phaseolina. Intl J Agric Biol 24 . DOI: 10.17957/IJAB/15.1457

Krak K, Vit P, Belyayev A, Douda J, Hreusova L, Mandak B (2016) Allopolyploid origin of Chenopodium album s. str. (Chenopodiaceae): a molecular and cytogenetic insight. Plos One 11:e0161063

Lichtenthaler HK, Buschmann C (2001) Chlorophylls and carotenoids: measurement and characterization by UV-VIS spectroscopy. In: Current protocols in food analytical chemistry. Wiley, New York, pp F4.3.1-F4.3.8

Liu B, Ji S, Zhang H, Wang Y, Liu Z (2020) Isolation of Trichoderma in the rhizosphere soil of Syringa oblata from Harbin and their biocontrol and growth promotion function. Microbiol Res 235:126445

Mahour K, Mishra A, Kumar A, Vihan VS (2008) Preliminary pharmacognostical and phytochemical investigation on Feronia elephantum corr. fruit. J Pharm Res 1:45-48

Malik MA, Singh Q (1980) Gas chromatography-mass spectrometry analysis and total phenolic contents of various crude extracts from the fruits of Datura metel L. J Taibah Univ Sci 7:209-215

Maurya S, Singh R, Singh DP, Singh HB, Singh UP, Srivastava JS (2008) Management of collar rot of chickpea (Cicer arietinum) by Trichoderma harzianum and plant growth promoting rhizobacteria. J Plant Prot Res 48: 347-358

Muthukathan G, Mukherjee P, Salaskar D, Pachauri S, Mukherjee PK (2020) Secretome of Trichoderma virens induced by banana roots - identification of novel fungal proteins for enhancing plant defence. Physiol Mol Plant Pathol 110:101476

Rabinal C, Bhat S (2020) Identification of differentially expressed genes in Trichoderma koningii IABT1252 during its interaction with Sclerotium rolfsii. Curr Microbiol 77:396-404

Ramanujam MM, El-Saeed RA, Bondock S (2012) Recent advances in 4-hydroxycoumarin chemistry. Part 1: Synthesis and reactions. Arab J Chem 14:17-24

Riaz T, Khan S, Javaid A (2010) Management of Fusarium corn rot of gladiolus by using leaves of allelopathic plants. Afr J Biotechnol 9:4681-4686

Sarkar A, Patel JS, Yadav S, Sarma BK, Srivastava JS, Singh HB (2014) Studies on rhizosphere-bacteria mediated biotic and abiotic stress tolerance in chickpea (Cicer arietinum L.). Vegetos 27:158-169

Semina YV, Shcherbakova LA, Slezina MP, Odintsova TI (2016) Studying the activity of Chenopodium album seed extracts and Fusarium sambucinum culture liquid against several plant pathogenic fungi. Agric Biol 51:739-745 
Shoaib A, Shehzad A, Javaid A, Akhtar S, Awan ZA (2019) Evaluation of biocontrol strategies and its synergistic interaction permitting the chickpea plant to trigger the appropriate defense responses against Sclerotium rolfsii. Biologia 65(2):329-334

Shrestha U, Dee ME, Piya S, Ownley BH, Butler DM (2020) Soil inoculation with Trichoderma asperellum, T. harzianum or Streptomyces griseoviridis prior to anaerobic soil disinfestation (ASD) does not increase ASD efficacy against Sclerotium rolfsii germination. Appl Soil Ecol 147:103383

Sumi K, Nao T, Sharma MB, Chakruno P, Sema T, Chishi AJ, Kent N (2018) In vitro evaluation of native bioagents isolates against stem rot of pigeonpea caused by Sclerotium rolfsii. J Food Legume 31:194-195

Sun S, Sun F, Deng D, Zhu X, Duan C, Zhu Z (2020) First report of southern blight of mung bean caused by Sclerotium rolfsii in China. Crop Prot 130: 105055

van Elsas JD, Postma J (2007) Suppression of soil-borne phytopathogens by compost, In DiazLF, deBertoldi M, Bidlingmaier W, Stentiford E (ed), Compost science and technology, vol. 8. Elsevier, Amsterdam, The Netherland. pp.: 201-214

Vinodkumar S, Indumathi T, Nakkeeran S (2017) Trichoderma asperellum (NVTA2) as a potential antagonist for the management of stem rot in carnation under protected cultivation. Biol Control 113:58-64

Wonglom P, Daengsuwan W, Ito SI, Sunpapao A (2019) Biological control of Sclerotium fruit rot of snake fruit and stem rot of lettuce by Trichoderma sp. T76-12/2 and the mechanisms involved. Physiol Mol Plant Pathol 107:1-7

\section{Publisher's Note}

Springer Nature remains neutral with regard to jurisdictional claims in published maps and institutional affiliations.

\section{Submit your manuscript to a SpringerOpen ${ }^{\circ}$ journal and benefit from:}

- Convenient online submission

- Rigorous peer review

- Open access: articles freely available online

High visibility within the field

- Retaining the copyright to your article

Submit your next manuscript at $\boldsymbol{\nabla}$ springeropen.com 